\title{
Financialization and Outsourcing in a Different Guise: The Ethical Chaos of Workforce Localization in the United Arab Emirates
}

\author{
Valerie Priscilla Goby
}

Received: 16 June 2014/ Accepted: 2 July 2014/Published online: 19 July 2014

(c) The Author(s) 2014. This article is published with open access at Springerlink.com

\begin{abstract}
This paper addresses the tension between the government policy to increase the number of citizens working in the private sector in the United Arab Emirates and the organizational preference for employing expatriate workers. Currently a dominant construal of the limited success of the policy is that the local workforce, traditionally employed largely in government positions, is unwilling to commit to the perceived greater rigor of the private sector. The author reconceptualizes the issue as one deriving from a principle of corporate financialization in which companies claim the right to optimize their labor costs as much as possible. This paper briefly discusses corporate financialization, overviews the workforce localization program in the United Arab Emirates, termed Emiratization, highlights the reasons cited for its limited success, and argues that this is due to corporate strategy of selecting their workforce according to financial and rights-related criteria. The issue is an ethical one in that a local population, the natural labor force, is marginalized in a national context of immigration laws permitting the large scale importation of cheaper and more compliant foreign labor.
\end{abstract}

Keywords Corporate financialization - Stereotypes · United Arab Emirates - Workforce localization

\section{Corporate Financialization and Outsourcing}

In recent decades, corporate financialization, "the increasing dominance of the finance industry in the sum

V. P. Goby $(\bowtie)$

College of Business, Zayed University, P. O. Box 19282, Dubai,

United Arab Emirates

e-mail:Valeriegoby@gmail.com; Valerie.goby@zu.ac.ae total of economic activity, of financial controllers in the management of corporations, of financial assets among total assets" (Dore 2002, p. 116), has determined the decisions of many companies worldwide (Das 2011). As part of the culture of financialization or maximum utilization of human and financial assets, many companies choose to offshore their operations to developing economies with lower salary scales, lower operational costs, and lower requirements relating to the provision of benefits to workers. The USA has been at the forefront of this practice with a very large number of companies outsourcing operations (Gordon and Zimmerman 2010). The impact on workforces in the countries located has been revealed to be less positive than commonly proposed (Kaplinsky 2000), and the impact on the retrenched workers in the country of original operations is typically negative, at times, even in the very long term (Kletzer 2001; Madrick 2004). While financialization increases profits for shareholders, it frequently results in reduced employee salary ratios (Álvarez Peralta 2011). Moreover, not only individual workers suffer, but also entire micro-economies of the areas of original operations can be devastated. An example is the case of Cadbury, a company with a long exemplary history of keen concern for worker and community welfare (Rowlinson and Hassard 1993). In 2010, a takeover bid was accepted from the US food giant, Kraft, which, while agreeing at the time of the takeover to maintain operations in England, later shifted production to Poland to reduce costs. The impact of this corporate relocation was that a long standing community and its micro-economic structures were shattered (Kelly 2011). An examination of how offshoring affects workers who are outsourced and the impact of offshoring on national and global economies is beyond the scope of this paper but the reader is referred to Levy (2005) who provides a relevant account and challenges the view 
that offshoring "is simply another form of trade with mutual benefits" (Levy 2005, p. 685) and to Robertson et al. (2010) for stakeholder views on the ethics of outsourcing.

\section{The UAE's Corporate Landscape}

The United Arab Emirates (UAE) has developed as a highly attractive economic hub, and in terms of ease of doing business there, it ranks $19^{\text {th }}$ out of the 148 countries surveyed in the Global Competitiveness Report (Schwab 2013). It has welcomed many MNCs and has established a variety of free zones in which companies enjoy considerable autonomy in conducting their businesses. In 2012, the emirate of Dubai alone garnered USD8 billion in foreign direct investment (Bitar 2013). The UAE imposes no currency restrictions or corporate or individual taxation, and its infrastructure and technological readiness are advanced (Schwab 2013).

Another major advantage corporations enjoy in the UAE is that its immigration laws permit the wide scale importation of workers from low GDP countries willing to work for not a great deal more than they would in their home countries. While much discussion on minimum wage has occurred in recent years, there is yet no general practice mandated (Gulf News 2013). It therefore offers a compelling environment for companies that wish to enjoy the benefits of a highly developed infrastructure without having to pay the salary scales usually associated with such infrastructures.

\section{Expatriate Workforce in the UAE}

Just as the UAE is an attractive place for foreign countries to set up business in, so too is it an appealing destination for expatriate workers. Emiratis make up only $16.5 \%$ of the country's population of six million which includes 1.75 million Indians, 1.25 Pakistanis, 0.5 million Bangladeshis, and one million other Asians (Sambidge 2009). Of the $99.5 \%$ foreign workers in the private sector, more than $80 \%$ come from nations with low per capita GDPs such as the countries of the Indian subcontinent, Africa, and the Philippines. For such nationals, the salary scales in the UAE are far higher than those of their home countries. In addition, many of these workers' home countries display increasingly poor employment conditions (Marois 2012). Such conditions make these nationals likely to comply with whatever workforce practices they encounter in the companies of their host country.

Another important factor for companies employing foreign labor is that should a foreign worker lose her/his job, her/his work permit and right to reside in the UAE is canceled, so the threat of dismissal is keenly felt. For companies, this translates into a substantial workforce with a highly compliant attitude willing to work for remuneration packages far inferior to those offered in developed countries but still within the well-supported, advanced business environment the UAE offers.

\section{The Emiratization Policy}

Like other countries in the Arabian Gulf, the UAE capitalized on its oil revenues to develop infrastructure and stimulate its economy. The UAE's oil boom began in the 1960 s at which time the population was a mere 119,000 (Lahmeyer 2001). Educational levels among the local population were low and infrastructure was lacking. The lack of locally available qualified labor was resolved by recruiting vast numbers of foreign workers of all levels of technical expertise from a variety of countries who were drawn to the UAE by higher salaries (Chemingui and Roe 2007; Forstenlechner 2008; Rees et al. 2007).

As the country's infrastructure developed so too did the educational sector which was keenly prioritized and heavily invested in. Currently the country boasts an advanced educational system which ranks 15 th out of the 148 countries surveyed in the Global Competitive Report (Schwab 2013) in terms of quality of third-level education. Given this progress and the soaring birth rate (Al-Waqfi and Forstenlechner 2010), UAE citizens now represent a large pool of qualified workers. However, their rising numbers and advanced educational qualifications are not reflected in their participation in the private sector workforce and the number of Emiratis in the private sector is calculated at $0.5 \%$ or 19,874 of the $3,895,695$ workers in the private sector (Al Khan 2012). Traditionally, they favored the public sector as this held greater prestige, offered better benefits (Al-Waqfi and Forstenlechner 2010), and allowed them to feel that they were developing their community and building up the country (Al Khan 2012). Another reason for locals to be wary of entering the private sector is that they prioritize job security, and the UAE private sector is known for its practice of hiring and firing at will (Al-Waqfi and Forstenlechner 2012). However, the public sector has now been saturated and the government is aware of the need to ensure private sector opportunities for locals (Al-Waqfi and Forstenlechner 2010).

Government figures calculate unemployment among Emiratis at 40,000 or $15 \%$ (Salem and Dajani 2013) although figures as high as $28 \%$ have been cited (Trenwith 2013). Unemployment among locals caused by over-reliance on imported labor was a consequence of the open overseas recruitment policy that had not been anticipated 
when the UAE opened its labor market to vast numbers of foreign workers (Forstenlechner 2008). In the 1990s, the government began to implement an affirmative action plan, termed Emiratization (www.emiratisation.org) to ensure that the increasingly qualified local population is absorbed into positions in the private sector (Forstenlechner 2008). The National Human Resource Development and Employment Authority (TANMIA) was established in 1999 with the objective of attaining full employment within the national labor force, reducing the reliance on foreign labor and developing market-oriented skills among locals (www.tanmia.ae). While the short-term goal is to reduce unemployment among citizens, its long-term objective is to establish a more stable labor market (Malik 2012) and accrue the socio-economic benefits that such stability can bring (Al-Waqfi and Forstenlechner 2010).

\section{How Corporations are Responding to the Requirements of the Emiratization Policy}

The Emiratization program has not been made law (Salem and Dajani 2013) and to date has had limited success with private companies slow to commit to localization of their workforces (Forstenlechner 2010; Waqas 2013). Figures for 2010 reckon the number of Emiratis in the public sector at $26 \%$ and a mere $0.5 \%$ in the private sector; in 2012, only 1,700 Emiratis were recruited by private sector companies and only 1,000 in 2013 (Salem and Dajani 2013). Companies have resisted arguing that locals have more work-related rights than expatriates, expect higher salaries than similarly qualified Asian workers, and are more difficult to dismiss than expatriates (England and Kerr 2009). Given the requirement to employ a certain number of locals, some companies have attempted to find ways around this. One such response has been the advent of "ghost Emiratization" in which companies claim to employ locals who do not in fact exist or who are paid a nominal monthly sum for agreeing to be officially recorded as an employee even though they have never worked there. An attempt to eliminate this practice has been made with the introduction of fines of AED 20,000 (USD5,445) for companies found to engage in it (Salem 2010).

\section{Socio-psychological Issues Emerging from the Emiratization Policy and Workforce Integration}

Apart from the response of companies, the reaction of expatriate workers to the new appearance of Emiratis within their ranks and their willingness to accept them as part of their work team is highly influential in the success of the Emiratization policy. Byrne (1971) similarity attraction paradigm is relevant here. This is a social-psychological theory that postulates that the greater the similarity between two people, the more they will tend to like each other and become allies. Local workers are typically viewed by expatriates as very different: they are citizens who naturally have the right to reside in the country regardless of their employment status, they enjoy the benefit of a set of generous social welfare offerings (Al Gergawi 2008), and their dismissal is more complicated than that of an expatriate (Harry 2007). They are also, of course, in numerical and cultural terms, a distinct minority among the expatriate majority in private companies $(0.5 \%$ overall). This lack of identity leads to a strong dynamic of social categorization and prototype-based depersonalization of Emiratis by expatriates (Hogg and Terry 2000). That is, in the changing reality in which locals are entering what had been the almost exclusive domain of expatriate workers, these expatriate workers categorize local workers to help plot their behavior toward them (Hogg and Terry 2000) and to diminish the new uncertainty of their changing work environment (Tajfel 1981). Indeed, the response of expatriate workers to the entry of local coworkers in the UAE workforce is often analogous to that adopted by host country nationals (HCNs) who practice obstructionist behavior toward expatriate workers because of some sense of resentment (Toh and DeNisi 2005). Some initial UAE studies document the difficulty experienced by locals in the UAE private sector workforce (Al-Ali 2008) and the exclusionary practices adopted by expatriate workers toward Emirati co-workers which negatively impact local workers' sense of self-efficacy (Al-Waqfi and Forstenlechner 2012). Their real integration is hampered and expatriate workers manage to maintain a competitive edge in terms of productivity leading to disengagement of local workers and increased resignation rates (Ahmed 2008).

This dynamic of nationality-based group identity is reinforced by the fact that many companies draw the bulk of their foreign workforce from a single country thus setting the ground for strong in-groups ties based on national origin. While the detrimental effect of employing largely from the same nationality group has been noted and the government is attempting to curb this practice by increasing the immigration costs companies pay for recruiting from the same country (Salem 2010), large nationality clusters within individual companies are still the norm. In addition, and very significantly, the vast majority of expatriate workers in the UAE are from countries with highly collectivist cultural patterns, such as India, Pakistan, Bangladesh, and the Philippines (Hofstede et al. 2010). Collectivism gives rise to strong in-group and out-group categorizations so the practice of casting others as out- 
groups due to national origins is already a culturally established impulse. A common consequence of such an ingroup/out-group divide is the creation of stereotypical images which serve to establish some sense of superiority among the weaker group (Tsui and O'Reilly 1989). This is very much the case in the UAE where the deep local/ expatriate divide in private sector contexts has led to the generation of a set of stereotypes relating to local workers. Some typical commonplaces include that they are demanding and unwilling to work as much as expatriates (Al-Waqfi and Forstenlechner 2010). So, in short, not only do local workers find it difficult to secure a private sector position, but when they do, they are likely to suffer exclusion within the workplace.

\section{Whose Sense of Entitlement? Local Workers' or Corporations'?}

A significant amount of discussion both in the academic literature and the business world hinges on the idea that Emirati workers are demanding and on what is termed the Emirati sense of entitlement (Al Gergawi 2008; Al-Waqfi and Forstenlechner 2012; Forstenlechner and Rutledge 2010). Al Gergawi (2008) identifies it as stemming from a history of generous benefits provided to nationals within the public sector, benefits based on welfare rather than performance criteria. While this concept of their sense of entitlement is bandied about as a datum, it actually merits considerable discussion in terms of what valid expectations are. Clearly demands and expectations of a worker from the UAE, a country with a per capita GDP of USD42,080, will be vastly different from those of workers from counties with per capita GDPs of USD829 such as in Bangladesh or USD2,765 such as in the Philippines (World Bank 2013). The expectations of UAE nationals are dismissed as excessive when, in fact, they can only seem excessive if the standard is set by non-comparable countries displaying poor economic indicators. The issue is not whether they are demanding or not, but whether, given the high economic status of their country, workers should be expected to accept the conditions that may seem acceptable and even attractive to nationals from countries with vastly inferior economic health and worker welfare cultures. To use a parallel scenario, one is unlikely to question the validity of a Norwegian or Swiss national expecting superior remunerative and work conditions than a Bangladeshi or an Indian national. An awareness of this contradiction among nationals emerges in a study of UAE private sector workforce conditions which quotes one local respondent thus, "We are a rich country Thank God - and the government pays well because it can afford to do so. It is our right as nationals to have jobs that pay well" (Al-Waqfi and Forstenlechner 2012, p. 617). To illustrate the UAE situation further we can employ an analogous example. In the UK, for example, the current minimum wage for persons over 21 is GBP6.31 (USD10.64) per hour (https://www.gov.uk/national-minimum-wagerates). This applies to all workers, even foreign workers residing in the UK for a short time (http://www.hmrc.gov. uk/migrantworkers/nmw.htm\#1). In India, the average minimum hourly rate is USD0.28 (Pocha 2014). If the UK were to heavily liberalize its immigration and minimum wage laws, then companies could recruit large numbers of workers from, say, India and pay them, say GDP1.50 (USD2.53) per hour with basic accommodation, a massive improvement on the Indian minimum wage and a massive saving for the UKbased company. But we could hardly envision a situation in which UK nationals could be expected to tolerate competing with such workers for employment. We can identify the key issue as the sense of entitlement of corporations to employ the cheaper labor available to enhance their profit margins rather than the allegedly unrealistic sense of entitlement of local workers.

Clearly one major cause of this situation of such an unequal labor market is the UAE government's wish to be an open economy based on free market principles. However, the considerable lack of restrictions present in immigration and recruitment is affecting the development of a strong indigenous workforce. Schlosser (2001), pp. 260-261 point is highly relevant: "The great challenge now facing countries throughout the world is how to find a proper balance between the efficiency and the amorality of the market.... An economic system promising freedom has too often become a means of denying it, as the narrow dictates of the market gain precedence over more important democratic values."

\section{Socio-economic, Political, and Ethical Impact of Free Influx of Foreign Workers}

What occurs in the UAE is a widespread phenomenon in the Gulf region where significant oil revenues to finance infrastructure development suddenly permitted the importing of foreign labor which continued after the local populations became large enough and qualified enough to assume roles hitherto held by foreign workers. The neighboring countries of Oman (Al-Lamki 1998, 2005), Saudi Arabia (Al-Dosary and Rahman 2005; Sadi and AlBuraey 2009), Kuwait (Chemingui and Roe 2007), Bahrain (Oxford Business Group 2007), and Qatar (http://www. qatarization.com.qa) have all experienced a similar exclusion of the local workforce necessitating government intervention. The Middle East has "the potential to be a formidable international economic player. The vast natural and human resources and its strategic geographical position 
place the Middle East at the center of the global stage, an attractive theater for competing global powers" (Ali 1999, p. 102). However, this potential development as a key actor in the world can hardly be played out in a socially and culturally meaningful way if the local populations of these countries are marginalized from the nucleus of professional and economic activity.

Traditionally in positive economic conditions, the opportunity to work within one's own place was ensured as industrial operations relied on local workers. This right is being eroded through the increasing dominance of corporate financialization and concomitant subjugation of labor for profit and disregard for the communities within which businesses operate. We can identify two approaches influenced by corporate financialization which contribute to the lack of tenable employment opportunities. The first is the well-known one occurring in developed economies in which labor and minimum wage laws are well established and workers lose employment when their companies abandon these countries in favor of lower labor cost economies. The second is what is happening in wealthy emerging economies with free inflow of labor such as the UAE where local workforces are rejected in favor of cheaper workers from poorer emerging economies. This latter can be described as a different kind of outsourcingjobs are outsourced away from the natural workforce, the local community, to transient guest workers. Both represent examples of a climate in which "the sole purpose of organizations is the maximization of shareholder value, with businesses having no wider obligations or accountability" (Grey 2013:105).

Perhaps one should also briefly consider the approach of the home country governments to their expatriate labor forces and the ethical issue involved in the tolerance of a substantial proportion of their workforce preferring to work overseas. The UAE is the sixth largest source of remittances in the world, and in 2012, expatriate workers in the country sent UDS20 billion back to their home countries mostly to India, Pakistan, Egypt, the Philippines, Sri Lanka, and Bangladesh (Carroll 2014). The faltering economies of many of these countries are supported by this inflow of remittances, rendering economic and political restructuring less immediate. And again this has major socio-economic impact on these countries as breadwinners leave their homes to go overseas in search of viable livelihoods. Many of these emerging countries are quickly absorbing the ethos of financialization and adopting "emerging finance capitalism" characterized by "the fusion of the interests of domestic and foreign financial capital in the state apparatus as the institutionalized priorities and overarching social logic guiding the actions of state managers and government elites, often to the detriment of labor" (Marois 2012, p. 10).

\section{Corporate Accountability}

Evidence indicates that Emirati workers are typically engaging well in the private sector and appreciate its dynamic environment over the public sector (Bell 2014) and the opportunities it offers for career advancement ( $\mathrm{Al}$ Marzouqi 2012), even in blue-collar positions (Al Subaihi 2014). Despite this success, negative stereotypes endure and "those at the very top of organizations, the well informed and the decision makers are even stronger in their stereotyping of citizens than those further down the corporate ladder, independent of whether they are expatriates or citizens themselves" (Al-Waqfi and Forstenlechner 2010, p. 377). This suggests that such stereotypes are sustained as part of a corporate justification for employing expatriates (Al Khan 2012). And, within the UAE context of unrestrained inflow of foreign workers and the "lack of detail in requirements, rationalization, compliance and applicability criteria" (Al-Waqfi and Forstenlechner 2010, p. 377) of the Emiratization policy itself, the myth and the implications of imputed inefficiency are permitted to endure. While scholars have established certain base criteria for general corporate accountability (Waddock 2004), corporate accountability in terms of employing members of the local community rather than imported, more cost-efficient, transient labor warrants further investigation.

Open Access This article is distributed under the terms of the Creative Commons Attribution License which permits any use, distribution, and reproduction in any medium, provided the original author(s) and the source are credited.

\section{References}

Ahmed, A. (2008, April 7). Expats make up 99\% of private sector staff in UAE. Gulf News. http://gulfnews.com/news/gulf/uae/ employment/expats-make-up-99-of-private-sector-staff-in-uae-1. 96744.

Al Gergawi, M. (2008, September 11). Emiratisation and the curse of entitlement. The National. http://www.zawya.com/blogs/mis haal/080912081800/.

Al Khan, M. N. (2012, November 7). Statistics suggest sorry state of Emiratisation in private sector. The National. http://www. thenational.ae/news/uae-news/statistics-suggest-sorry-state-ofemiratisation-in-private-sector.

Al-Lamki, S. (1998). Barriers to Omanization in the private sector: The perceptions of Omani graduates. International Journal of Human Resource Management, 9(2), 377-397.

Al-Lamki, S. (2005). The role of the private sector in Omanization: The case of the banking industry inthe Sultanate of Oman. International Journal of Management, 22(2), 176-198.

Al Marzouqi, N. M. (2012). Emiratisation strategy at Jumeirah and its objectives: Emirati perspectives. Unpublished MSc dissertation. School of Business, British University of Dubai. http:// bspace.buid.ac.ae/bitstream/handle/1234/91/90024.pdf?se quence $=1 \&$ isAllowed $=\mathrm{y}$. 
Al Subaihi, T. (2014, April 8). Production line at Al Ain water factory is manned entirely by Emiratis. The National. http://www. thenational.ae/uae/heritage/production-line-at-al-ain-water-fac tory-is-manned-entirely-by-emiratis.

Al-Ali, J. (2008). Emiratisation: Drawing UAE nationals into their surging economy. The International Journal of Sociology and Social Policy, 28(9), 365-379.

Al-Dosary, A., \& Rahman, S. (2005). Saudiization (localization): A critical review. Human Resource Development International, $8(4), 495-502$.

Ali, A. (1999). Middle East competitiveness in the $21^{\text {st }}$ century. The Academy of Management Executive, 13(1), 102-108.

Álvarez Peralta, I. (2011). Financialization and the wage-labor nexus: The case of France political economy and the outlook for capitalism conference, Paris, July 2012. http://www.assoecono miepolitique.org/political-economy-outlook-for-capitalism/wpcontent/uploads/2012/06/Alvarez_Ignacio_Financialization-andthe-wage-labor-nexus-the-case-of-France.pdf.

Al-Waqfi, M., \& Forstenlechner, I. (2010). Stereotyping of citizens in an expatriate-dominated labour market: Implications for workforce localisation policy. Employee Relations, 32(4), 364-381.

Al-Waqfi, M., \& Forstenlechner, I. (2012). Of private sector fear and prejudice: The case of young citizens in an oil-rich Arabian Gulf economy. Personnel Review, 41(5), 609-629.

Bell, J. (2014, February 3). Young generation of Emiratis wants a career not just a job, summit told. The National. http://www. thenational.ae/uae/emiratisation/young-generation-of-emiratiswant-a-career-not-just-a-job-summit-told.

Bitar, Z. (2013, April 28). FDI inflow into Dubai reached \$8b in 2012. Gulf News. http://gulfnews.com/business/general/fdi-inflowinto-dubai-reached-8b-in-2012-1.1176338.

Byrne, D. (1971). Attraction Paradigm. New York: Academic Press.

Carroll, L. (2014, May 28). UAE has made enormous progress in the protection it offers to workers. The National. http://www. thenational.ae/uae/government/uae-has-made-enormous-progressin-the-protection-it-offers-to-workers?utm_source $=$ Communicator\& utm_medium $=$ Email\&utm_content $=\& u t m \_c a m p a i g n=U A E \% 20$ has $\% 20$ made $\% 20$ enormous $\% 20$ progress $\% 20$ in $\% 20$ the $\% 20$ pro tection $\% 20$ it $\% 20$ offers $\% 20$ to $\% 20$ workers.

Chemingui, M., \& Roe, T. (2007). Petroleum revenues in Gulf Cooperation Council countries and their labor market paradox. Journal of Policy Modeling, 30, 491-503.

Das, S. (2011). Extreme money: The masters of the universe and the cult of risk. Australia: Penguin.

Dore, R. (2002). Stock market capitalism and its diffusion. New Political Economy, 7(1), 115-121.

England, A., and Kerr, S. (2009, February 19). UAE to safeguard jobs of nationals. Financial Times, p. 8. http://www.ft.com/intl/cms/s/ 0/7dfbc81e-fe0d-11dd-932e-000077b07658. html\#axzz2sIzzj5YQ.

Forstenlechner, I. (2008). Workforce nationalization in the UAE: Image versus integration. Education, Business and Society: Contemporary Middle East Issues, 1(2), 82-91.

Forstenlechner, I. (2010). Workforce localization in emerging Gulf economies: The need to fine-tune HRM. Personnel Review, 39(1), 135-152.

Forstenlechner, I., \& Rutledge, E. (2010). Unemployment in the Gulf: Time to update the "social contract". Middle East Policy, 17(2), $38-51$.

Gordon, C., \& Zimmerman, A. (2010). Fair shares: A preliminary framework and case analyzing the ethics of offshoring. Science and Engineering Ethics, 16(2), 325-353.

Grey, C. (2013). A very short, fairly interesting and reasonably cheap book about studying organization (3rd ed.). London: Sage.
Gulf News (2013, July 11). UAE labour law section 5-payment of wages. http://gulfnews.com/uaessentials/ask-the-law/uae-labourlaw-section-5-payment-of-wages-1.1208188.

Harry, W. (2007). Employment creation and localization: the crucial human resource issues for the GCC. International Journal of Human Resource Management, 18(1), 132-146.

Hofstede, G., Hofstede, G. J., \& Minkov, M. (2010). Cultures and organizations: Software of the mind. Revised and expanded (3rd ed.). New York: McGraw-Hill.

Hogg, M. A., \& Terry, D. J. (2000). Social identity and selfcategorization processes in organizational contexts. Academy of Management Review, 25, 121-140.

Kaplinsky, R. (2000). Spreading the gains from globalisation: What can be learned from value chain analysis? IDS working paper 110, Institute for Development Studies, Sussex University, Brighton. http://www.ids.ac.uk/files/Wp110.pdf.

Kelly, C. (2011). Broken chocolate factory pledge devastates Keynsham. http://www.bbc.co.uk/news/uk-england-bristol-12126550.

Kletzer, L. (2001). Job loss from imports: Measuring the costs. Washington, DC: Institute for International Economics.

Lahmeyer, J. (2001). The United Arab Emirates-Historical demographical data of the urban centers. Retrieved October 28, 2013. http://www.populstat.info/Asia/unarabet.html.

Levy, D. L. (2005). Offshoring in the new global political economy. Journal of Management Studies, 42(3), 685-693.

Madrick, J. (2004, March 18). As job exports rise, some economists rethink the mathematics of free trade. New York Times. http://www. nytimes.com/2004/03/18/business/economic-scene-job-exports-risesome-economists-rethink-mathematics-free-trade.html.

Malik, J. R. (2012, August 6). Ministry of Labour threatens heavy fines. UniqueAuction.ae. http://www.uniqueauction.ae/blog/min istry-labour-threatens-heavy-fines/3062.

Marois, T. (2012). States, banks, and crisis: Emerging finance capitalism in Mexico and Turkey. Cheltenham: Edward Elgar.

Oxford Business Group (2007). The report: Emerging Bahrain 2007. Oxford.

Pocha, J. S. (2014, April 17). The price of sweat: America's minimum wage debate echoes in India. The World Post. http://www.huffington post.com/jehangir-s-pocha/america-wage-india_b_5168110.html.

Rees, C., Mamman, A., \& Bin-Braik, A. (2007). Emiratization as a strategic HRM change initiative: Case study evidence from a UAE petroleum company. International Journal of Human Resource Management, 18(1), 33-53.

Robertson, C. J., Lamin, A., \& Livanis, G. (2010). Stakeholder perceptions of offshoring and outsourcing: The role of embedded issues. Journal of Business Ethics, 95(2), 167-189.

Rowlinson, M., \& Hassard, J. (1993). The invention of corporate culture: A history of the histories of Cadbury. Human Relations, 46(3), 299-326.

Sadi, M., \& Al-Buraey, M. (2009). A framework of the implementation process: The case of Saudiization. International Management Review, 5(1), 70-106.

Salem, O. (2010, December 11). Firms face big fines for "ghost Emiratization". The National. http://www.thenational.ae/news/ uae-news/firms-face-big-fines-for-ghost-emiratisation.

Salem, O. \& Dajani, H. (2013, November 19). FNC would like Emiratisation to become law. The National. http://www.thena tional.ae/uae/government/fnc-would-like-emiratisation-tobecome-law.

Sambidge, A. (2009, October 7). UAE population hits 6 m, Emiratis make up $16.5 \%$. ArabianBusiness. Com. http://www.arabianbusi ness.com/uae-population-hits-6m-emiratis-make-up-16-5-12137. html.

Schlosser, E. (2001). Fast food nation: The dark side of the allAmerican meal. Boston: Houghton Mifflin. 
Schwab, K. (2013). Global Competitiveness Report 2013-2014. http:// www3.weforum.org/docs/WEF_GlobalCompetitivenessReport_ 2013-14.pdf.

Tajfel, H. (1981). Human groups and social categories: Studies in social psychology. New York: Cambridge University Press.

Toh, S. M., \& DeNisi, A. S. (2005). A local perspective to expatriate success. Academy of Management Executive, 19(1), 132-146.

Trenwith, C. (2013, November 12). Emiratisation failing to cut UAE jobless rate - Al Mulla. Arabian Business. http://www.arabianbu siness.com/emiratisation-failing-to-cut-uae-jobless-rate-almulla-526101.html.
Tsui, A. S., \& O'Reilly, C. A. (1989). Beyond simple demographic effects: The importance of relational demography in superiorsubordinate dyads. Academy of Management Journal, 32(2), 402-423.

Waddock, S. (2004). Creating corporate accountability: Foundational principles to make corporate citizenship real. Journal of Business Ethics, 50(4), 313-327.

Waqas, M. (2013, August 12). Emiratisation plan wanes, report blames business. Arabian Gazette. http://arabiangazette.com/ emiratisation-plan-blames-business-20130812/.

World Bank. (2013). GDP per capita. http://data.worldbank.org/ indicator/NY.GDP.PCAP.CD. 